\title{
MENINGKATNYA TRANSAKSI PEMBAYARAN UANG ELEKTRONIK BERBASIS SERVER DIMASA PANDEMI COVID-19 BERDASARKAN PERSPEKTIF SYARIAH
}

\author{
Intan Kesuma Ratu'), Muhammad Iqbal Fasa'), Suharto ${ }^{3)}$ \\ Universitas Islam Negeri Raden Intan Lampung \\ 1)intankesumaratu@gmail.com, 2) miqbalfasa@radenintan.ac.id, \\ 3)prof.suharto@radenintan.ac.id
}

\begin{abstract}
Abstrak: Sehubungan dengan kemajuan teknologi pada zaman modern ini, terciptalah uang digital atau yang disebut dengan uang elektronik. Uang elektronik merupakan alat pembayaran dalam bentuk uang elektronik, dimana nilai uangnya disimpan dalam media elektronik tertentu. Penelitian ini dilakukan bertujuan untuk mengetahui faktor-faktor penyebab meningkatnya transaksi pembayaran menggunakan uang elektronik terkhusus uang elektronik berbasis server dimasa pandemi. Penelitian dilakukan berupa kualitatif deskriptif dengan mengumpulkan data menggunakan studi pustaka dan meresume dari hasil teori atau pendapat yang telah dilakukan sebelumnya. Hasilnya menunjukkan bahwa Pembatasan Sosial Berskala Besar (PSBB) menyebabkan mobilitas masyarakat terbatas berpotensi meningkatkan transaksi uang elektronik dan kebijakan physical distancing mendorong masyarakat menggunakan uang elektronik berbasis server. Meningkatnya transaksi uang elektronik di masa pandemi Covid-19 juga disebabkan oleh kesadaran masyarakat, akan meningkatnya risiko penularan virus Covid-19 melalui uang kertas.
\end{abstract}

Kata Kunci: Uang Elektronik, Berbasis Server, Covid-19, Transaksi

\begin{abstract}
In connection with technological advances in this modern era, digital money is created or what is called electronic money. Electronic money is a means of payment in the form of electronic money, where the value of the money is stored in certain electronic media. This study was conducted with the aim of knowing the factors causing the increase in payment transactions using electronic money, especially server-based electronic money during the pandemic. The research was conducted in the form of descriptive qualitative by collecting data using literature studies and a resume from the results of theories or opinions that have been done previously. The results show that Large-Scale Social Restrictions (PSBB) cause limited public mobility, potentially increasing electronic money transactions and physical distancing policies encourage people to use server-based electronic money. The increase in electronic money transactions during the Covid-19 pandemic was also caused by public awareness of the increased risk of transmission of the Covid-19 virus through paper money.
\end{abstract}

Keywords: Electronic Money, Server-Based, Covid-19, Transactions 


\section{PENDAHULUAN}

Uang adalah segala sesuatu yang dapat digunakan oleh masyarakat sebagai alat tukar atau alat pembayaran yang sah untuk pembelian barang atau jasa. Alat pembayaran telah mengalami perubahan mulai dari sistem barter hingga ditemukannya uang sebagai alat transaksi pembayaran ${ }^{1}$. Sistem pembayaran merupakan bagian penting dalam perekonomian suatu negara, khususnya untuk menjamin terlaksananya transaksi pembayaran yang dilakukan oleh masyarakat ${ }^{2}$. Sistem pembayaran adalah suatu sistem yang meliputi seperangkat aturan, lembaga, dan mekanisme yang digunakan untuk melakukan transfer dana guna memenuhi suatu kewajiban yang berasal dari suatu kegiatan ekonomi ${ }^{3}$.

Seiring dengan perkembangan zaman, dunia teknologi dan informasi juga mengalami berkembang, salah satunya dalam sistem pembayaran khususnya dalam transaksi jual-beli 4 . Kemajuan teknologi di era globalisasi berjalan seiring dengan perubahan gaya hidup yang mempengaruhi sistem peradaban manusia ${ }^{5}$. Sehubungan dengan kemajuan teknologi pada zaman modern ini, terciptalah uang digital atau yang disebut dengan uang elektronik. Bentuknya tidak lagi dalam bentuk lembaran atau logam yang dapat dihitung, tetapi dalam bentuk data digital. Uang elektronik memiliki nilai tersimpan atau dibayar di muka ketika nilai moneter tertentu disimpan pada media elektronik milik individu dan nilai uang dalam uang elektronik berkurang karena konsumen menggunakannya untuk melakukan pembayaran ${ }^{6}$.

Mengacu pada definisi yang dikeluarkan oleh Bank for International Settlement, uang elektronik adalah nilai tersimpan atau produk prabayar di mana catatan dana atau nilai yang tersedia untuk konsumen disimpan pada perangkat elektronik yang biasanya dimiliki

\footnotetext{
${ }^{1}$ Hutami A Ningsih, Endang M Sasmita, and Bida Sari, 'Pengaruh Persepsi Manfaat, Persepsi Kemudahan Penggunaan, Dan Persepsi Risiko Terhadap Keputusan Menggunakan Uang Elektronik (QRIS) Pada Mahasiswa', Jurnal IKRA-ITH Ekonomika, 4.1 (2021), 1-9.

2 Anggun Yuli Wijaya, Imam Mukhlis, and Linda Seprillina, 'Analisis Pengaruh E-Money, Volume Transaksi Elektronik Dan Suku Bunga Terhadap Jumlah Uang Beredar Di Indonesia Pada Masa Sebelum Dan Sesudah Pandemi COVID-19', Jurnal Ekonomi, Bisnis Dan Pendidikan, 1.2 (2021), 135-45 <https://doi.org/10.17977/um066v1i22021p135-145>.

3 Bank Indonesia, Sistem Pembayaran \& Pengelolaan Uang Rupiah, 2020 $<$ https://www.bi.go.id/id/edukasi/Pages/Apa-itu-Uang-Elektronik.aspx>.

${ }^{4}$ Dwi Rorin, Mauludin Insana, and Ria Susanti Johan, 'Analisis Pengaruh Penggunan Uang Elektronik Terhadap Perilaku Konsumtif Mahasiswa', Jurnal Ekonomi, 17.2 (2021), 413-34.

5 Yuni Priskila Ginting and Astrid Athina Indradewi, 'Transaksi Keuangan Mencurigakan Dari Uang Elektronik Pada Masa Pandemi Covid 19', 7.2 (2021), 455-76 <https://doi.org/10.15294/snhunnes.v7i2.724>.

${ }^{6}$ Nabila Zulfatien Nisa' Al-Uluwiyah, 'Pendapat Para Ulama Kabupaten Gresik Terhadap Penggunaan Uang Elektronik Menurut Hukum Islam', Jurnal Hukum Bisnis Islam, 11.1 (2021), 79-109.
} 
konsumen ${ }^{7}$. Uang elektronik atau electronic money (E-Money), pada dasarnya adalah uang tunai dengan bentuk non-fisik atau non-tunai ${ }^{8}$.

Transaksi uang elektronik di Indonesia terus meningkat dari tahun ke tahun ${ }^{9}$. Uang elektronik merupakan salah satu dampak dari perkembangan teknologi di sektor ekonomi 10 . Saat ini masyarakat lebih menyukai menggunakan sistem pembayaran yang mudah, cepat dan nyaman dengan menggunakan sistem pembayaran secara elektronik ${ }^{11}$. Menurut ${ }^{12}$ kemajuan teknologi menjanjikan kecepatan dan kemudahan. Saat ini, kemajuan teknologi pada sektor perekonomian khususnya keuangan telah memungkinkan transaksi hanya dengan satu sentuhan jari di handphone anda yang terhubung ke internet.

Wabah Covid-19 telah menyebar ke seluruh dunia termasuk ke Indonesia, oleh karena itu WHO menyatakan bahwa fenomena ini sebagai sebuah Pandemi ${ }^{13}$. Penyebaran virus corona atau Covid-19 "dari manusia ke manusia" terjadi sangat cepat dalam penularannya, banyak orang yang terinfeksi virus ini hingga meninggal dunia. Penyebarannya sangat cepat melalui perilaku berjabat tangan atau menyentuh benda dengan kedua tangan, lalu tanpa sengaja menyentuh hidung atau mata. Sifat virus ini tidak bisa dilihat dengan mata, sehingga interaksi apapun di sekitar orang tanpa gejala atau orang yang positip Covid-19 yang beraktivitas diluar bisa menulari orang lain. Penyebaran virus ini yang sangat cepat, maka pemerintah Indonesia mengeluarkan kebijakan guna penanganan secara cepat dan tepat, salah satunya dengan melakukan antisipasi dengan protokol kesehatan dan bekerja dari rumah ${ }^{14}$. Indonesia juga salah satu negara yang mengambil kebijakan untuk mengatasi pandemi COVID19 dengan memperhatikan aspek ekonomi melalui pemberlakuan kebijakan Pembatasan

${ }^{7}$ Marc Hollanders, 'Innovations in Retail Payments and the BIS Statistics on Payment and Settlement Systems', Bank for International Settlements: IFC Bulletin, 31, 2009, 431-38 <https://econpapers.repec.org/bookchap/bisbisifc/31-31.htm>.

${ }^{8}$ Suharni, 'Uang Elektronik (E-Money) Ditinjau Dari Perspektif Hukum Dan Perubahan Sosial', Jurnal Spektrum Hukum, 15.1 (2018), 15-43 <https://doi.org/10.35973/sh.v15i1.1108>.

${ }^{9}$ Ningsih, Sasmita, and Sari.

10 Munawir and Mahbub, 'Tinjauan Penggunaan Uang Elektronik Dalam Perspektif Hukum Syariah', Jurnal Hukum Islam, Ekonomi Dan Bisnis, 7.1 (2021), 51-64.

11 Sukma Indra and Zuliana Rofiqoh, 'Transaksi Emoney Terhadap Layanan Gopay Pada Aplikasi Gojek Perspektif Ekonomi Syariah', Universitas Tanjungpura Pontianak, 15.2 (2019), 49-58 $<$ https://doi.org/10.37035/ajh.v15i2.2176>.

12 Ngafifi, (2014)

13 Indra Rahmatullah, 'Jaminan Hak Kesehatan Pekerja Work From Office Selama Masa PSBB Covid-19', Buletin Hukum Dan Keadilan, 4.1 (2020), 57-62.

${ }^{14}$ Ade Parlaungan Nasution, Ibnu Rasyid Munthe, and Bhakti Helvi Rambe, 'Transaksi Uang Dan Dompet Digital Pada Saat Masa Pandemi Virus Corona ( Covid-19)', Jurnal Teknologi Informasi Dan Komunikasi, 12.1 (2021), 1-6. 
Sosial Berskala Besar (PSBB). PSBB adalah pembatasan ruang bagi masyarakat untuk melakukan aktivitas di luar rumah demi upaya physical distancing 15 .

Pandemi Covid-19 telah mempengaruhi perilaku manusia dalam beberapa hal, termasuk penggeseran dari sistem pembayaran konvensional menjadi digital ${ }^{16}$. Setiap hari masyarakat melakukan transaksi jual beli kebutuhan sehari-hari menggunakan alat pembayaran berupa uang tunai atau uang kertas. Uang kertas itu salah satu media penyebaran virus corona karena virus yang tidak terlihat, tidak dapat diketahui apakah uang tersebut bersih dari virus corona ${ }^{17}$.

Meningkatnya penggunaan sistem pembayaran digital di era pandemi Covid-19, harus seiringi dengan pemahaman konsumen terhadap sistem keamanan dan prosedur keamanan penyelenggara layanan pembayaran elektronik 18. Beberapa faktor yang mendorong penggunaan sistem pembayaran elektronik, selain disebabkan oleh pembatasan mobilitas juga karena adanya kemudahan dan kerumitan yang cukup rendah dalam penggunaan sistem pembayaran digital ${ }^{19}$. Dengan penggunaan uang elektronik diharapkan dapat mencegah penyebaran virus lebih luas ${ }^{20}$.

Tujuan peneliatian ini untuk mengkaji penyebab meningkatnya transaksi pembayaran menggunakan uang elektronik, terkhusus uang elektronik kerbasis server dimasa pandemi Covid-19 berdasarkan perspektif islam.

\section{KAJIAN TEORITIS}

\section{Pengertian Uang Elektronik}

Sistem pembayaran dalam transaksi ekonomi telah berkembang pesat seiring dengan perkembangan teknologi yang canggih. Didukung dengan semakin banyaknya perusahaan atau pusat perbelanjaan di Indonesia yang telah banyak menerima transaksi pembayaran

\footnotetext{
15 Rahmatullah.

16 Rasistia Wisandianing Primadineska, 'Pengaruh Penggunaan Sistem Pembayaran Digital Terhadap Perilaku Beralih Di Era Pandemi COVID-19', Telaah Bisnis, 21.2 (2020), 89-98 <http://journal.stimykpn.ac.id/indeks.php/tb>.

17 Nasution, Munthe, and Rambe.

18 Primadineska.

${ }^{19}$ Aldilla Iradianty and Bayu Rima Aditya, 'Indonesian Student Perception in Digital Payment', Jurnal Manajemen Bisnis, 17.4 (2020), 518-30 <https://doi.org/10.38043/jmb.v17i4.2713>.

${ }^{20}$ Firman Katon and Ulfa Yuniati, 'Fenomena Cashless Society Dalam Pandemi Covid-19 (Kajian Interaksi Simbolik Pada Generasi Milenial)', Jurnal Signal, 8.2 (2020), 134-45 <http://jurnal.ugj.ac.id/index.php/Signal>.
} 
dengan menggunakan sistem pembayaran non tunai karena dianggap mudah, aman, cepat, nyaman, dan efesien ${ }^{21}$.

Menurut 22, uang elektronik merupakan alat pembayaran dalam bentuk uang elektronik, dimana nilai uangnya disimpan dalam media elektronik tertentu. ${ }^{23}$ mendefinisikan uang elektronik (E-Money) sebagai nilai tersimpan atau produk prabayar di mana catatan dana atau nilai yang tersedia untuk konsumen disimpan pada perangkat yang milik konsumen. Nilai elektronik dibeli oleh konsumen dan berkurang setiap kali konsumen menggunakan perangkat untuk melakukan pembelian ${ }^{24}$. Uang elektronik (E-Money) adalah uang yang digunakan secara elektronik dalam transaksi internet. Transaksi ini melibatkan penggunaan jaringan komputer (seperti internet dan sistem penyimpanan harga digital) 25 .

Menurut pasal 1 ayat (3) Peraturan Bank Indonesia Nomor 20/6/PBI/2018 tentang Uang Elektronik. Uang elektronik adalah alat pembayaran yang memenuhi unsur-unsur sebagai berikut 26 :

1. Diterbitkan berdasarkan nilai uang yang disetor terlebih dahulu kepada penerbit

2. Nilai uang disimpan secara elektronik dalam suatu media server atau chip

3. Nilai uang elektronik yang dikelola oleh penerbit bukan merupakan simpanan sebagaimana dimaksud dalam Undang-Undang yang mengatur mengenai perbankan. Nilai uang elektronik adalah nilai uang yang disimpan secara elektronik dalam suatu media server atau chip yang dapat dipindahkan untuk kepentingan transaksi pembayaran dan/atau transfer dana .

\section{Dasar Hukum Penyelenggaraan Uang Elektronik}

1. Peraturan Bank Indonesia No. 20/6/PBI/2018 Tahun 2018 tentang Uang Elektronik (Electronic Money)

21 Firmansyah and Ihsan Dacholfany, Uang Elektronik Dalam Perspektif Islam (Metro: CV. Iqro, 2018).

22 Bank Indonesia (2020)

23 Bank for International Settlement (2000)

24 Hollanders.

25 Firmansyah and Dacholfany.

26 Badan Pemeriksa Keuangan, Peraturan Bank Indonesia Nomor 20/6/PBI/2018 Tentang Uang Elektronik, Peraturan.Bpk.Go.Id, 2018 <https://peraturan.bpk.go.id/Home/Details/135874/peraturan-bi-no-206pbi2018tahun-2018> [accessed 7 October 2021]. 
2. Peraturan Bank Indonesia No. 18/17/PBI/2016 Tahun 2016 tentang Perubahan Kedua atas Peraturan Bank Indonesia Nomor 11/12/PBI/2009 tentang Uang Elektronik (Electronic Money)

3. Peraturan Bank Indonesia No. 16/8/PBI/2014 Tahun 2014 tentang Perubahan atas Peraturan Bank Indonesia Nomor 11/12/PBI/2009 tentang Uang Elektronik (Electronic Money)

4. Peraturan Bank Indonesia No. 11/12/PBI/2009 Tahun 2009 tentang Uang Elektronik (Electronic Money) ${ }^{27}$

\section{Jenis-jenis Uang Elektronik}

1. Berdasarkan Pencatatan Data Identitas Pengguna Uang Elekronik Uang elekronik ditinjau dari jenis pencatatan data identitas pengguna uang elektronik dapat dibedakan menjadi 2, yaitu:

a. Registered artinya data identitas pemegang uang elektronik tercatat dan terdaftar pada penerbit. Nilai uang yang disimpan pada media chip atau server penerbit maksimum Rp. 5 juta.

b. Unregistered artinya data identitas pemegang uang elektronik tidak tercatat dan tidak terdaftar pada penerbit. Nilai uang yang disimpan pada media chip atau server penerbit maksimum Rp. 1 juta.

2. Berdasarkan Media Penyimpanan Uang Elekronik

Uang elektronik ditinjau dari media penyimpanan nilai uang elektronik yang digunakan ada 2, yaitu:

a. Uang elektronik berbasis chip (chip based)

1) Nilai uang disimpan di dalam media chip.

2) Verifikasi transaksi lebih cepat, karena bersifat off-line.

3) Sangat cocok sebagai alat pembayaran yang bersifat massal dengan nilai transaksi kecil, tetapi frekuensinya tinggi, seperti pembayaran tiket kereta api, parkir, tol.

b. Uang elektronik berbasis server (server based)

1) Nilai uang disimpan di dalam server penerbit.

2) Verifikasi transaksi lebih lambat, karena harus on-line kepada penerbit.

\footnotetext{
${ }^{27}$ Badan Pemeriksa Keuangan.
} 
3) Kurang cocok sebagai alat pembayaan yang bersifat massal, tetapi lebih cocok untuk micro/retail payment lainnya ${ }^{28}$.

3. Berdasarkan Masa Berlaku Media Uang Elektronik

Bentuk uang elektronik berdasarkan masa berlakunya dapat dibedakan sebagai berikut:

a. Reloadable, Bentuk uang elektronik yang dapat diisi ulang jika masa berlaku medianya sudah habis maupun nilai uang elektronik sudah habis terpakai.

b. Disposable, Bentuk uang elektronik tidak dapat diisi ulang apabila masa berlaku habis maupun nilai uangnya habis terpakai.

4. Berdasarkan Jangkauan Penggunaanya

Bentuk uang elektronik berdasarkan jangkauan penggunaannya:

a. Singgle-Purpose, Jenis uang elektronik ini hanya dapat digunakan untuk melakukan pembayaran untuk satu jenis transaksi, seperti penggunaan uang elektronik saat membayar tol atau transportasi umum.

b. Multi-Purpose, Jenis uang elektronik yang dapat digunakan lebih dari satu kali transaksi pembayaran, seperti untuk pembayaran tol, tranportasi umum bahkan untuk berbelanja ${ }^{29}$.

\section{Kelebihan Pengunaan Uang Elektronik}

1. Lebih cepat dan nyaman dari pada uang tunai, khususnya untuk transaksi yang bernilai kecil (micro payment), karena konsumen tidak perlu menyediakan sejumlah uang pas untuk suatu transaksi atau harus menyimpan uang kembalian. Selain itu, saat menggunakan uang elektronik, kesalahan dalam menghitung uang kembalian dari suatu transaksi tidak akan terjadi.

2. Waktu yang dibutuhkan untuk menyelesaikan transaksi dengan uang elektronik lebih singkat dibandingkan transaksi dengan kartu kredit atau kartu debit, karena tidak harus memerlukan proses otorisasi online, tanda tangan maupun PIN. Selain itu, dengan transaksi offline, maka biaya komunikasi dapat dikurangi. Pengguna uang elektronik tidak perlu lagi berdesak-desakan dan mengantri di kasir.

${ }^{28}$ Firmansyah and Dacholfany.

${ }^{29}$ Munawir and Mahbub. 
3. Electronic value (jumlah uang) dapat diisi ulang kedalam kartu e-money melalui berbagai cara yang disediakan oleh issuer. Apabila nilai uang pada kartu elektronik telah habis maka pengguna dapat melakukan pengisian uang sehingga tidak perlu membeli baru uang elektronik.

4. Tidak ada lagi uang kembalian dalam bentuk barang (seperti permen) akibat padagang tidak mempunyai uang kembalian bernilai kecil (receh).

5. Sangat applicable (berlaku) untuk transaksi massal yang nilainya kecil tetapi frekuensinya tinggi, seperti: transportasi, parkir, tol, fast food, dll. 30

\section{Kekurangan Uang Elektronik}

1. Menuntut seseorang untuk mempelajari hal baru, terutama mereka yang tidak paham teknologi. Hal ini tentunya menjadi salah satu kendala saat penggunaan metode pembayaran dengan uang elektronik di masyarakat.

2. Layanan pendukung penggunaan uang elektronik masih kurang di beberapa daerah, terutama jika sedang berada di daerah-daerah pelosok yang minim akses khususnya internet. Oleh karena itu, penggunaan uang elektronik masih terbatas hanya di kota-kota besar saja.

3. Berisiko mengalami peretasan, karena berhubungan langsung dengan penggunaaan internet, tetapi untuk beberapa layanan uang elektronik tentu sudah memiliki proteksi yang dapat diandalkan. ${ }^{31}$

\section{Uang Elektronik Berdasarkan Perspektif Syariah}

Menurut fatwa Dewan Syariah Nasional ${ }^{32}$ menyatakan bahwa hukum uang elektronik secara umum diperbolehkan dengan ketentuan sebagai berikut:

1. Uang elektronik (e-money) adalah alat pembayaran yang memenuhi unsur-unsur sebagai berikut:

a. Diterbitkan berdasarkan jumlah nominal uang yang disetor terlebih dahulu kepada penerbit

${ }^{30}$ Firmansyah and Dacholfany.

31 Al-Uluwiyah.

32 Majelis Ulama Indonesia NO: 116/DSN-MUI/IX/20I7, 'Uang Elektronik Syariah', in Fatwa Dewan Syariah Nasional, 2017, pp. 1-12. 
b. Jumlah nominal uang disimpan secara elektronik dalam suatu media yang teregistrasi

c. Jumlah nominal uang elektronik yang dikelola oleh penerbit bukan merupakan simpanan sebagaimana dimaksud dalam undang-undang yang mengatur mengenai perbankan

d. Digunakan sebagai alat pembayaran kepada pedagang yang bukan merupakan penerbit uang elektronik tersebut

2. Uang elektronik syariah adalah uang elektronik yang sesuai dengan prinsip- prinsip syariah.

Terdapat beberapa akad yang berhubungan dengan mekanisme uang elektronik 33 yaitu sebagai berikut:

1. Akad Wadiah

Akad wadi'ah adalah akad penitipan uang antara pemegang uang elektronik dengan penerbit dengan syarat pemegang uang elektronik dapat mengambil/menarik/menggunakan kapan saja sesuai kesepakatan

2. Akad Qardh

Akad qardh adalah akad pinjaman dari pemegang uang elektronik kepada penerbit dengan syarat bahwa penerbit wajib mengembalikan uang yang diterima kepada pemegang kapan saja sesuai dengan kesepakatan

3. Akad Ijarah

Al-ijarah berasal dari kata al-ajru, yang berarti al-iwadhu (ganti). Menurut syara, al-ijarah adalah sejenis akad untuk mengambil manfaat dengan jalan pengganti ${ }^{34}$. Akad ijarah adalah akad pemindahan hak guna (manfaat) atas suatu barang atau jasa dalam waktu tertentu dengan pembayaran atau upah.

4. Akad Ju'alah

Akad ju'alah adalah akad untuk memberikan imbalan tertentu atas pencapaian hasil (natijah) yang ditentukan dari suatu pekerjaan.

\footnotetext{
${ }^{33}$ Majelis Ulama Indonesia NO: 116/DSN-MUI/IX/20I7.

${ }^{34}$ Harun Santoso and Anik, 'Analisis Pembiayaan Ijarah Pada Perbankan Syariah', Jurnal Ilmiah Ekonomi Islam, 01.02 (2015), 106-16.
} 
5. Akad wakalah bi al-ujrah

Akad wakalah adalah akad pemberian kuasa dari muwakkil kepada wakil untuk melakukan perbuatan hukum tertentu. Ujrah adalah imbalan yang harus dibayar atas jasa yang dilakukan oleh wakil 35. Akad wakalah bi al-ujrah adalah akad wakalah yang disertai dengan imbalan berupa ujrah (fee).

\section{Landasan Dasar Al-Qur'an dan Hadist}

Islam tidak melarang segala bentuk teknologi selama tidak bertentangan dengan ajarannya, Al-Qur'an menyatakan bahwa manusia adalah khalifah diatas muka bumi dan Allah menempatkan posisi alam ini untuk digunakan oleh manusia dengan usaha-usahanya yang baik. Firman Allah dalam surah Al-Baqarah ayat 29 yang berbunyi:

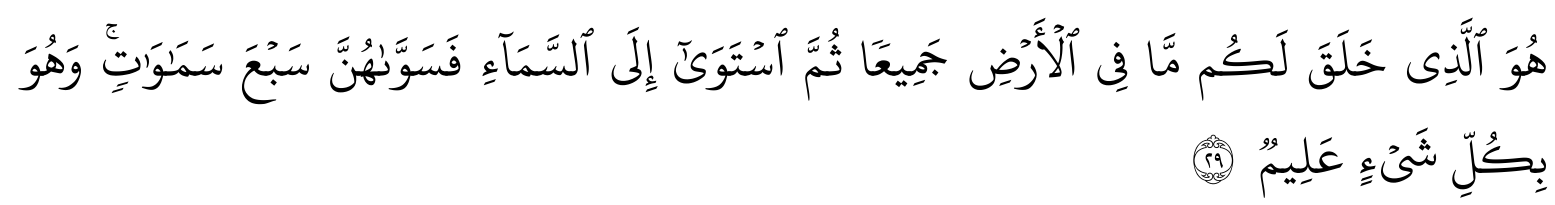

Artinya : Dialah Allah yang menjadikan segala yang ada di bumi untuk kamu dan dia berkehendak (menciptakan) langit, lalu dijadikannya tujuh langit dan dia maha mengetahui segala sesuatu.

Yang dimaksud ayat di atas ialah Allah yang menciptakan segala sesuatu yang ada di bumi untuk kamu (manusia). Dalam perspektif Islam, manusia sebagai khalifah harus menggunakan ilmu sebagai syarat utama dalam membangun peradaban dan teknologi modern yang digunakan dengan cara yang baik (makruf) dan bukannya untuk tujuan yang salah (munkar/ maksiat) ${ }^{36}$.

Berkaitan dengan perkembangan zaman dan teknologi, masyarakat saat ini cenderung menggunakan alat tukar elektronik atau uang elektronik (e-money). Uang elektronik sendiri merupakan alat tukar atau alat pembayaran dengan unsur digital. Saat ini banyak lembaga syariah yang mengeluarkan produk uang elektronik syariah dengan menggunakan akad

\footnotetext{
${ }^{35}$ Majelis Ulama Indonesia, 'Akad Wakalah Bi Al-Ujrah No: 113/DSN-MUI/IX/2017', Fatwa Dewan Syariah Nasional, 2017, pp. 1-9.

${ }^{36}$ Syifa Sekar Pramesti Kristiano, Perlindungan Hukum Bagi Konsumen Pengguna Uang Elektronik, Skripsi (UIN Syarif Hidayatullah Jakarta, 2021).
} 
Wadi'ah, akad Qardh, akad Ijarah, akad Ju'alah, akad Wakalah bi al-Ujrah ${ }^{37}$. Allah berfirman dalam surah Al-maidah ayat 1, yang berbunyi :

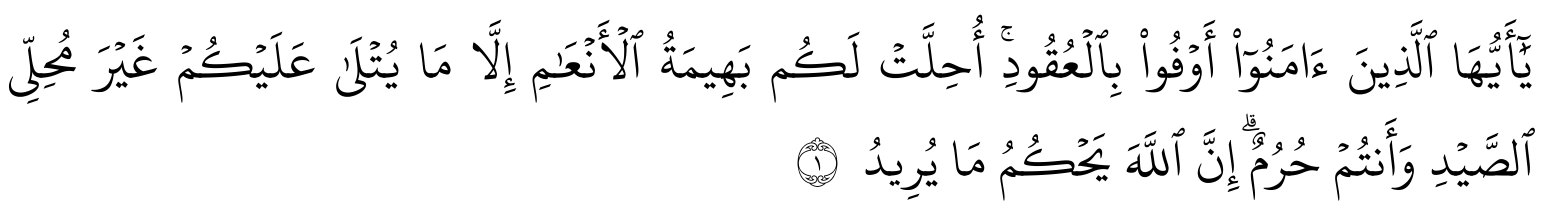

Artinya: Wahai orang" beriman penuhlah akad-akad kalian......

Uang elektronik pada dasarnya diperbolehkan, sesuai dengan Al-Qur'an surah al-Nisa' (4) ayat 29:

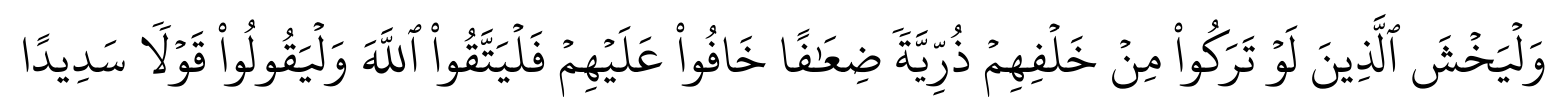

Artinya: Hai orang yang beriman! Janganlah kalian memakan(mengambil) harta orang lain secara batil, kecuali jika berupa perdagangan yang dilandasi atas suka rela diantara kalian.......

Dari ayat Al-Quran diatas bahwa manusia boleh bermuamalah dalam bidang ekonomi dengan cara yang benar dan melarang manusia memakan harta dengan cara yang bathil, juga dengan didasari saling ridha meridhai,saling rela, saling ikhlas ${ }^{38}$. Ayat bermuamalah ini pun dikuatkan dengan Hadits Rasulullah SAW yang diriwayatkan oleh Imam Muslim dari Aisyah dan dari Tsabit dari Anas:

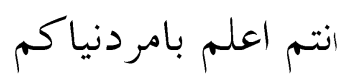

Artinya: Kalian lebih mengerti urusan dunia kalian.(HR. Muslim).

Hadis Nabi riwayat Ibnu Majah dari 'Ubadah bin al-Shamit r.a.,riwayat Ahmad dari Ibnu 'Abbas r.a., riwayat Malik dari bapaknya Yahya al-Mazini r.a. dan riwayat al-Hakim dan al-Dar al-Quthni dari Abu Sa'id al-Khudriy r.a.:

$$
\text { لاضررو لاضرار }
$$

37 Diana Santika, Analisis Produk Uang Elektronik Ovo Ditinjau Dari Perspektif Hukum Ekonomi Syariah., PhD Thesis (UIN Sunan Gunung Djati Bandung, 2020).

38 Muhammad Ridwan Firdaus, 'E-Money Dalam Perspektif Hukum Ekonomi Syariah', Jurnal Tahkim, XIV.1 (2018), 145-56. 
Artinya: Tidak boleh membahayakan/merugikan orang lain dan tidak boleh (pula) membalas bahaya (kerugian yang ditimbulkan oleh orang lain) dengan bahaya (perbuatan yang merugikannya).

\section{METODE PENELITIAN}

Metode yang digunakan dalam penelitian ini adalah metode kualitatif deskriptif, mendeskrifsikan suatu peristiwa atau kejadian yang kemudian digambarkan apa adanya tanpa manipulasi ${ }^{39}$. Pengumpulan data menggunakan studi pustaka ${ }^{40}$, mengumpulkan referensireferensi bentuk data berupa narasi atau kalimat, dokumen, teori pendapat, gagasan yang sudah ada sebelumnya yang kemudian dianalisis menggunakan teknik analisis data ${ }^{41}$.

Analisis data, mengolah data hasil pemikiran pendapat teori atau gagasan dari data sebelumnya. Pertama kali yang dilakukan dalam menganalisis data yaitu mereduksi data, memilih atau meresume hal-hal penting dari data yang ada. Selanjutnya mendisplay data, menguraikan data-data berupa teks narasi dalam bentuk grafik, bagan, catatan atau uraian singkat dan terakhir menarik kesimpulan 42 .

\section{HASIL DAN PEMBAHASAN}

Teknologi saat ini berkembang begitu pesat sehingga membuat transaksi keuangan menjadi lebih mudah. Uang elektronik sebagai pengganti uang tunai fisik berupa uang logam dan uang kertas dengan uang elektronik yang setara dan sebagai sebuah sistem yang memungkinkan seseorang untuk membayar barang atau jasa dengan cara mentransfer nomor dari satu komputer ke komputer lain ${ }^{43}$. Menurut ${ }^{44}$ sistem pembayaran dengan uang elektronik berbasis server merupakan salah satu inovasi teknologi yang terdapat dalam sektor

\footnotetext{
${ }^{39}$ Tjutja Soendari, 'Metode Penelitian Deskriptif', in Stuss, Magdalena \& Herdan, Agnieszka (Bandung, UPI, 2012), p. 17.

40 Wahyudin Darmalaksana, 'Metode Penelitian Kualitatif Studi Pustaka Dan Studi Lapangan' (Pre-print Digital Library UIN Sunan Gunung Djati Bandung, 2020).

41 Salsabila Sekar Wahri, 'Tanggung Jawab Hukum Penerbit Uang Elektronik Terhadap Kerugian Nasabah Pengguna Uang Elektronik Di BANK Mandiri', Skripsi (UIN Syarif Hidayatullah Jakarta, 2021).

42 Ahmad Rijali, 'Analisis Data Kualitatif', Jurnal Alhadharah, 17.33 (2018), 81-95.

43 Ferry Fabi Fadlillah, 'Sudah Saatnya Beralih Ke E-Money, Alat Pembayaran Zaman Now', Kemenkeu.Go.Id, 2018 <https://www.kemenkeu.go.id/publikasi/artikel-dan-opini/sudah-saatnya-beralih-ke-e-money-alatpembayaran-zaman-now/> [accessed 9 October 2021].

${ }^{44}$ Huda Qasim and Emad Abu-Shanab, 'Drivers of Mobile Payment Acceptance: The Impact of Network Externalities', Information Systems Frontiers, 18.5 (2016), 1021-34.
} 
pembayaran dengan memanfaatkan perangkat mobile sebagai media untuk melakukan transaksi keuangan seperti pembayaran dan transfer dana.

Pada tahun 2020, masyarakat dunia sedang bersama-sama menghadapi wabah Covid19 yang dinyatakan oleh World Health Organization (WHO) sebagai wabah yang menjadi perhatian internasional karena dianggap sebagai keadaan darurat kesehatan masyarakat 45 . Wabah ini mendorong masyarakat dunia untuk menerapkan gaya hidup yang baru untuk mencegah terjadinya penularan Covid-19 yang semakin meningkat, salah satunya di negara Indonesia ${ }^{46}$.

Pemerintah Indonesia mengeluarkan kebijakan Pembatasan Sosial Berskala Besar (PSBB) yang mengakibatkan terbatasnya mobilitas masyarakat. Pembatasan yang menyebabkan mobilitas masyarakat terbatas berpotensi meningkatkan transaksi elektronik. Pasalnya, masyarakat mulai memanfaatkan platform digital untuk bertransaksi saat pandemi 47. Pembatasan mobilitas masyarakat untuk memutus penyebaran virus Covid-19 menyebabkan perubahan pada transaksi keuangan, di mana penggunaan uang elektronik yang naik signifikan 48 .

Penyebaran virus Covid-19 berdampak pada kegiatan ekonomi termasuk pada perubahan sistem pembayaran yang dilakukan oleh masyarakat sebab munculnya kebijakan physical distancing. Kebijakan physical distancing yang didorong oleh WHO telah membuat masyarakat untuk melakukan aktivitas physical distancing, termasuk dalam melakukan transaksi pembayaran. Uang elektronik berbasis server adalah salah satu upaya untuk mencegah rantai penularan virus Covid-19. Masyarakat khawatir Covid-19 dapat tertular melalui uang fisik ${ }^{49}$. Contoh aplikasi uang elektronik berbasis server seperti GoPay, OVO, Dana, LinkAja, dll.

\footnotetext{
${ }^{45}$ Harapan Harapan and others, 'Coronavirus Disease 2019 (COVID-19): A Literature Review', Journal of Infection and Public Health, 13.5 (2020), 667-73 <https://doi.org/https://doi.org/10.1016/j.jiph.2020.03.019>.

46 Sisca Aulia, 'Pola Perilaku Konsumen Digital Dalam Memanfaatkan Aplikasi Dompet Digital', Jurnal Komunikasi, 12.2 (2020), 311-24 <https://doi.org/http://dx.doi.org/10.24912/jk.v12i2.9829>.

47 Herlina Kartika Dewi, 'PPKM Darurat Kerek Transaksi Uang Elektronik', Kontan.Co.Id, 2021 <https://keuangan.kontan.co.id/news/ppkm-darurat-kerek-transaksi-uang-elektronik> [accessed 9 October 2021].

48 Iqbal Dwi Purnama, 'Transaksi Uang Elektronik Terus Melejit Di Masa Pandemi', Sindenews.Com, 2021 $<$ https://ekbis.sindonews.com/read/495068/178/transaksi-uang-elektronik-terus-melejit-di-masa-pandemi1627463254> [accessed 9 October 2021].

49 Hendy Mustiko Aji, Izra Berakon, and Maizaitulaidawati Md Husin, 'COVID-19 and E-Wallet Usage Intention: A Multigroup Analysis Between Indonesia and Malaysia', Cogent Business and Management, 7 (2020), 116 <https://doi.org/10.1080/23311975.2020.1804181>.
} 
Sistem pembayaran berbasis teknologi saat ini memiliki peluang yang sangat besar. Hal ini karena adanya pandemi Covid-19 mengharuskan pemerintah mengeluarkan kebijakan bagi masyarakat untuk membatasi kegiatan yang berhubungan dengan interaksi sosial bersama orang lain. Kebijakan work from home dan physical distancing menjadi salah satu penyebab penggunaan uang elektronik berbasis server. Sistem pembayaran dengan uang elektronik berbasis server dapat membantu meminimalisir penyebaran Cocid-19 karena penggunaan uang kertas yang mana merupakan salah satu media penularan Covid-19 50.

Menggunakan uang elektronik berbasis server membuat kita menjadi praktis dan efisien karena tidak perlu menyediakan/ membawa-bawa uang tunai.. Memberikan kemudahan dan kenyamanan dalam penggunaannya. Terdapat fitur keamanan, sehingga transaksi lebih aman. Kecepatan transaksi, tidak perlu lagi menunggu antrian 51.

Uang elektronik meningkat pesat di masa pandemi Covid-19. Pada bulan April 2020 Bank Indonesia mencatat kenaikan transaksi uang elektronik selama pemberlakuan Pembatasan Sosial Berskala Besar (PSBB) mencapai 64,48\% pertahun. Sementara volume transaksi digital tumbuh 37,35 persen secara tahunan ${ }^{52}$. Pada bulan Maret 2021, Gubernur BI Perry Warjiyo mengatakan bahwa transakasi keuangan dan ekonomi digital mengalami pertumbuhan hal tersebut tercermin dari nilai transaksi uang elektronik sebesar Rp 21,4 triliun, atau tumbuh $42,46 \%$ tahun ${ }^{53}$.

Pandemi Covid-19 memaksa masyarakat harus melakukan pyshical distancing atau jaga jarak untuk memutus mata rantai penyebaran virus Covid-19. Oleh karena itu, diperlukan upaya dari masyarakat agar tetap menjaga jarak saat beraktivitas sehari-hari. Salah satu cara yang bisa dilakukan adalah menerapkan metode pembayaran nontunai (cashless), dengan metode pembayaran ini tentu masyarakat dapat meminimalkan kontak langsung saat bertransaksi. Hal ini dapat membantu dalam menekan penyebaran Covid-19. Organisasi Kesehatan Dunia (WHO) telah memperingatkan bahwa uang kertas mungkin dapat

\footnotetext{
${ }^{50}$ Rizka Elisa Rahmawati and M Ruslianor Maika, 'Penerapan Model UTAUT Terkait Akseptasi Mahasiswa Terhadap Cashless P a Yment Di Masa Pandemi CoVID-19', Jurnal Ekonomi Modernisasi, 17.1 (2021), 1-14.

51 Melly Indrawati and others, 'Penggunaan Aplikasi Dompet Digital Di Masa Pandemi Covid-19', Prosiding National Seminar on Accounting , Finance , Dan Ekonomics, 1.8 (2021), 235-47.

52 Kiki Safitri, 'Transaksi Digital Melonjak 64,48 Persen Saat PSBB', Kompas.Com, 2020 <https://money.kompas.com/read/2020/06/18/180000126/transaksi-digital-melonjak-64-48-persen-saatpsbb> [accessed 10 October 2020].

53 Rully R Ramli, 'BI Catat Transaksi Uang Elektronik Melonjak 42 Persen, Apa Pendorongnya?', Kompas.Com, 2021 <https://money.kompas.com/read/2021/04/21/082400626/bi-catat-transaksi-uang-elektronik-melonjak42-persen-apa-pendorongnya-.> [accessed 10 October 2021].
} 
menyebarkan Covid-19. Jadi, penggunaan transaksi uang elektronik lebih aman dibanding menggunakan uang kertas pada saat ini. ${ }^{54}$.

Pandemi Covid-19 telah mengubah kebiasaan atau perilaku masyarakat dalam melakukan transaksi pembayaran. Masyarakat saat ini perlahan mulai meninggalkan pembayaran secara tunai dan lebih memilih untuk melakukan transaksi dengan uang elektronik ${ }^{55}$. Menurut Handayani, Director of Consumer Business Bank BRI, meningkatnya transaksi elektronik di tengah pandemi disebabkan oleh kesadaran masyarakat. Akan meningkatnya risiko penularan virus Covid-19 melalui uang kertas. Masyarakat mulai takut untuk memegang uang tunai karena dianggap sebagai alat transfering virus Covid-19. Jika server base ada di ponsel, risiko penularan Covid-19 ini dapat dikontrol 56

\section{PENUTUP}

\section{Kesimpulan}

Uang elektronik merupakan alat pembayaran dalam bentuk uang elektronik, dimana nilai uangnya disimpan dalam media elektronik tertentu. Uang elektronik mengalami kenaikan pengggunanya setiap tahunnya dikarenakan uang elektronik merupakan alat pembayaran non tunai yang diaggap mudah, kenyaman, keamanan, cepat, dan efisien.

Pandemi Covid-19 menyebabkan Pemerintah Indonesia mengeluarkan kebijakan Pembatasan Sosial Berskala Besar (PSBB). Dimana Pembatasan tersebut menyebabkan mobilitas masyarakat terbatas berpotensi meningkatkan transaksi uang elektronik. Pandemi Covid-19 memaksa masyarakat harus melakukan pyshical distancing atau jaga jarak untuk memutus mata rantai penyebaran virus Covid-19. Kebijakan physical distancing yang didorong oleh WHO telah membuat masyarakat untuk melakukan aktivitas physical distancing, termasuk dalam melakukan transaksi pembayaran. Uang elektronik berbasis server adalah salah satu upaya untuk mencegah rantai penularan virus Covid-19. Masyarakat khawatir Covid-19 dapat tertular melalui uang fisik.

54 Anggara Wikan Prasetya, 'Transaksi Nontunai Jadi Salah Satu Cara Mencegah Penyebaran C0ovid-19', Kompas.Com, 2020 <https://money.kompas.com/read/2020/05/09/144045726/transaksi-nontunai-jadi-salahsatu-cara-mencegah-penyebaran-covid-19?page=all $>$ [accessed 9 October 2021].

55 Cantika Adinda Putri, 'Kantor Cabang \& ATM Ditinggal, Transaksi Digital Jadi Melesat', Cnbcindonesia.Com, 2021 <https://www.cnbcindonesia.com/market/20210729164035-17-264671/kantorcabang-atm-ditinggal-transaksi-digital-jadi-melesat> [accessed 9 October 2021].

56 Purnama. 
Pandemi Covid-19 mengubah kebiasaan atau perilaku masyarakat dalam melakukan transaksi pembayaran meninggalkan uang tunai dan memilih menggunakan uang elektronik. Meningkatnya transaksi elektronik di masa pandemi Covid-19 juga disebabkan oleh kesadaran masyarakat, akan meningkatnya risiko penularan virus Covid-19 melalui uang kertas. Masyarakat mulai takut untuk memegang uang tunai karena dianggap sebagai alat transfering virus Covid-19. Contoh aplikasi uang elektronik berbasis server seperti GoPay, OVO, Dana, LinkAja, dll.

\section{Saran}

Saran dari peneliti untuk peneliti selanjutnya dapat membuat koesioner yang berhubungan dengan meningkatnya transaksi uang elektronik berbasis server dimasa pandemi Covid-19. 


\section{DAFTAR PUSTAKA}

Aji, Hendy Mustiko, Izra Berakon, and Maizaitulaidawati Md Husin, 'COVID-19 and E-Wallet Usage Intention: A Multigroup Analysis Between Indonesia and Malaysia', Cogent Business and Management, 7 (2020), 1-16 <https://doi.org/10.1080/23311975.2020.1804181>

Al-Uluwiyah, Nabila Zulfatien Nisa', 'Pendapat Para Ulama Kabupaten Gresik Terhadap Penggunaan Uang Elektronik Menurut Hukum Islam', Jurnal Hukum Bisnis Islam, 11.1 (2021), 79-109

Aulia, Sisca, 'Pola Perilaku Konsumen Digital Dalam Memanfaatkan Aplikasi Dompet Digital', Jurnal Komunikasi, 12.2 (2020), 311-24 <https://doi.org/http://dx.doi.org/10.24912/jk.v12i2.9829>

Badan Pemeriksa Keuangan, Peraturan Bank Indonesia Nomor 20/6/PBI/2018 Tentang Uang Elektronik, Peraturan.Bpk.Go.Id, 2018 <https://peraturan.bpk.go.id/Home/Details/135874/peraturan-bi-no-206pbi2018tahun-2018> [accessed 7 October 2021]

Bank for International Settlement, Survey of Electronic Money Development (Basel, 2000)

Bank Indonesia, Apa Itu Uang Elektronik, 2020 <https://www.bi.go.id/id/edukasi/Pages/Apa-itu-Uang-Elektronik.aspx>

- - - Sistem Pembayaran \& Pengelolaan Uang Rupiah, 2020 <https://www.bi.go.id/id/edukasi/Pages/Apa-itu-Uang-Elektronik.aspx>

Darmalaksana, Wahyudin, 'Metode Penelitian Kualitatif Studi Pustaka Dan Studi Lapangan' (Pre-print Digital Library UIN Sunan Gunung Djati Bandung, 2020)

Dewi, Herlina Kartika, 'PPKM Darurat Kerek Transaksi Uang Elektronik', Kontan.Co.Id, 2021 <https://keuangan.kontan.co.id/news/ppkm-darurat-kerek-transaksi-uang-elektronik> [accessed 9 October 2021]

Fadlillah, Ferry Fabi, 'Sudah Saatnya Beralih Ke E-Money, Alat Pembayaran Zaman Now', Kemenkeu.Go.Id, 2018 <https://www.kemenkeu.go.id/publikasi/artikel-danopini/sudah-saatnya-beralih-ke-e-money-alat-pembayaran-zaman-now/> [accessed 9 October 2021]

Firdaus, Muhammad Ridwan, 'E-Money Dalam Perspektif Hukum Ekonomi Syariah', Jurnal Tahkim, XIV.1 (2018), 145-56

Firmansyah, and Ihsan Dacholfany, Uang Elektronik Dalam Perspektif Islam (Metro: CV. Iqro, 2018)

Ginting, Yuni Priskila, and Astrid Athina Indradewi, 'Transaksi Keuangan Mencurigakan Dari Uang Elektronik Pada Masa Pandemi Covid 19', 7.2 (2021), 455-76 <https://doi.org/10.15294/snhunnes.v7i2.724>

Harapan, Harapan, Naoya Itoh, Amanda Yufika, Wira Winardi, Synat Keam, Haypheng Te, and 
others, 'Coronavirus Disease 2019 (COVID-19): A Literature Review', Journal of Infection and Public Health, 13.5 (2020), 667-73

<https://doi.org/https://doi.org/10.1016/j.jiph.2020.03.019>

Hollanders, Marc, 'Innovations in Retail Payments and the BIS Statistics on Payment and Settlement Systems', Bank for International Settlements: IFC Bulletin, 31, 2009, 431-38 <https://econpapers.repec.org/bookchap/bisbisifc/31-31.htm>

Indra, Sukma, and Zuliana Rofiqoh, 'Transaksi Emoney Terhadap Layanan Gopay Pada Aplikasi Gojek Perspektif Ekonomi Syariah', Universitas Tanjungpura Pontianak, 15.2 (2019), 49-58 <https://doi.org/10.37035/ajh.v15i2.2176>

Indrawati, Melly, Khansa Nabila, Maria Oktaviana Manewalu, and Rizky Firmansyah, 'Penggunaan Aplikasi Dompet Digital Di Masa Pandemi Covid-19', Prosiding National Seminar on Accounting , Finance, Dan Ekonomics, 1.8 (2021), 235-47

Iradianty, Aldilla, and Bayu Rima Aditya, 'Indonesian Student Perception in Digital Payment', Jurnal Manajemen Bisnis, 17.4 (2020), 518-30 <https://doi.org/10.38043/jmb.v17i4.2713>

Katon, Firman, and Ulfa Yuniati, 'Fenomena Cashless Society Dalam Pandemi Covid-19 (Kajian Interaksi Simbolik Pada Generasi Milenial)', Jurnal Signal, 8.2 (2020), 134-45 <http://jurnal.ugj.ac.id/index.php/Signal>

Kristiano, Syifa Sekar Pramesti, Perlindungan Hukum Bagi Konsumen Pengguna Uang Elektronik, Skripsi (UIN Syarif Hidayatullah Jakarta, 2021)

Majelis Ulama Indonesia, 'Akad Wakalah Bi Al-Ujrah No: 113/DSN-MUI/IX/2017', Fatwa Dewan Syariah Nasional, 2017, pp. 1-9

Majelis Ulama Indonesia NO: 116/DSN-MUI/IX/20I7, 'Uang Elektronik Syariah', in Fatwa Dewan Syariah Nasional, 2017, pp. 1-12

Manurung, Abdi Putra, Pinondang Nainggolan, and Dian Purba, 'PENGARUH PENGGUNAAN UANG ELEKTRONIK TERHADAP TINGKAT KONSUMSI MASYARAKAT DI KOTA PEMATANGSIANTAR PADA SAAT PANDEMI COVID-19', Jurnal Ekonomi Pembangunan, 3.2 (2021), 68-80

Munawir, and Mahbub, 'Tinjauan Penggunaan Uang Elektronik Dalam Perspektif Hukum Syariah', Jurnal Hukum Islam, Ekonomi Dan Bisnis, 7.1 (2021), 51-64

Nasution, Ade Parlaungan, Ibnu Rasyid Munthe, and Bhakti Helvi Rambe, 'Transaksi Uang Dan Dompet Digital Pada Saat Masa Pandemi Virus Corona ( Covid-19)', Jurnal Teknologi Informasi Dan Komunikasi, 12.1 (2021), 1-6

Ngafifi, Muhamad, 'Kemajuan Teknologi Dan Pola Hidup Manusia Dalam Perspektif Sosial Budaya', Jurnal Pembangunan Pendidikan: Fondasi Dan Aplikasi, 2.1 (2014), 33-47

Ningsih, Hutami A, Endang M Sasmita, and Bida Sari, 'Pengaruh Persepsi Manfaat, Persepsi Kemudahan Penggunaan, Dan Persepsi Risiko Terhadap Keputusan Menggunakan Uang Elektronik (QRIS) Pada Mahasiswa', Jurnal IKRA-ITH Ekonomika, 4.1 (2021), 1-9 
Prasetya, Anggara Wikan, 'Transaksi Nontunai Jadi Salah Satu Cara Mencegah Penyebaran C0ovid-19', Kompas.Com, 2020

<https://money.kompas.com/read/2020/05/09/144045726/transaksi-nontunai-jadisalah-satu-cara-mencegah-penyebaran-covid-19?page=all $>$ [accessed 9 October 2021]

Primadineska, Rasistia Wisandianing, 'Pengaruh Penggunaan Sistem Pembayaran Digital Terhadap Perilaku Beralih Di Era Pandemi COVID-19', Telaah Bisnis, 21.2 (2020), 89-98 $<$ http://journal.stimykpn.ac.id/indeks.php/tb>

Purnama, Iqbal Dwi, 'Transaksi Uang Elektronik Terus Melejit Di Masa Pandemi', Sindenews.Com, $2021<$ https://ekbis.sindonews.com/read/495068/178/transaksiuang-elektronik-terus-melejit-di-masa-pandemi-1627463254> [accessed 9 October 2021]

Putri, Cantika Adinda, 'Kantor Cabang \& ATM Ditinggal, Transaksi Digital Jadi Melesat', Cnbcindonesia.Com, 2021 <https://www.cnbcindonesia.com/market/20210729164035-17-264671/kantorcabang-atm-ditinggal-transaksi-digital-jadi-melesat> [accessed 9 October 2021]

Qasim, Huda, and Emad Abu-Shanab, 'Drivers of Mobile Payment Acceptance: The Impact of Network Externalities', Information Systems Frontiers, 18.5 (2016), 1021-34

Rahmatullah, Indra, 'Jaminan Hak Kesehatan Pekerja Work From Office Selama Masa PSBB Covid-19', Buletin Hukum Dan Keadilan, 4.1 (2020), 57-62

Rahmawati, Rizka Elisa, and M Ruslianor Maika, 'Penerapan Model UTAUT Terkait Akseptasi Mahasiswa Terhadap Cashless P a Yment Di Masa Pandemi COVID-19', Jurnal Ekonomi Modernisasi, 17.1 (2021), 1-14

Ramli, Rully R, 'BI Catat Transaksi Uang Elektronik Melonjak 42 Persen, Apa Pendorongnya?', Kompas.Com, 2021 <https://money.kompas.com/read/2021/04/21/082400626/bicatat-transaksi-uang-elektronik-melonjak-42-persen-apa-pendorongnya-.> [accessed 10 October 2021]

Rijali, Ahmad, 'Analisis Data Kualitatif', Jurnal Alhadharah, 17.33 (2018), 81-95

Rorin, Dwi, Mauludin Insana, and Ria Susanti Johan, 'Analisis Pengaruh Penggunan Uang Elektronik Terhadap Perilaku Konsumtif Mahasiswa', Jurnal Ekonomi, 17.2 (2021), 41334

Safitri, Kiki, 'Transaksi Digital Melonjak 64,48 Persen Saat PSBB', Kompas.Com, 2020 <https://money.kompas.com/read/2020/06/18/180000126/transaksi-digitalmelonjak-64-48-persen-saat-psbb> [accessed 10 October 2020]

Santika, Diana, Analisis Produk Uang Elektronik Ovo Ditinjau Dari Perspektif Hukum Ekonomi Syariah., PhD Thesis (UIN Sunan Gunung Djati Bandung, 2020)

Santoso, Harun, and Anik, 'Analisis Pembiayaan Ijarah Pada Perbankan Syariah', Jurnal Ilmiah Ekonomi Islam, 01.02 (2015), 106-16

Situmorang, Maria Kristina, 'Pengaruh Perilaku Konsumen Terhadap Penggunaan Uang Elektronik ( Dompet Digital) Sebagai Alat Pembayaran Pada Masa Pandemi Covid - 19 
Di Kota Medan', Jurnal Ilmiah Magister Manajemen, 4.1 (2021), 123-30

<http://jurnal.umsu.ac.id/index.php/MANEGGIO>

Soendari, Tjutja, 'Metode Penelitian Deskriptif', in Stuss, Magdalena \& Herdan, Agnieszka (Bandung, UPI, 2012), p. 17

Suharni, 'Uang Elektronik (E-Money) Ditinjau Dari Perspektif Hukum Dan Perubahan Sosial', Jurnal Spektrum Hukum, 15.1 (2018), 15-43 <https://doi.org/10.35973/sh.v15i1.1108>

Wahri, Salsabila Sekar, 'Tanggung Jawab Hukum Penerbit Uang Elektronik Terhadap Kerugian Nasabah Pengguna Uang Elektronik Di BANK Mandiri', Skripsi (UIN Syarif Hidayatullah Jakarta, 2021)

Yuli Wijaya, Anggun, Imam Mukhlis, and Linda Seprillina, 'Analisis Pengaruh E-Money, Volume Transaksi Elektronik Dan Suku Bunga Terhadap Jumlah Uang Beredar Di Indonesia Pada Masa Sebelum Dan Sesudah Pandemi COVID-19', Jurnal Ekonomi, Bisnis Dan Pendidikan, 1.2 (2021), 135-45 <https://doi.org/10.17977/um066v1i22021p135145> 